EWA DANOWSKA* - KRAKÓW

\title{
SPUŚCIZNA RĘKOPIŚMIENNA KS. JANA AMBROŻEGO WADOWSKIEGO W BIBLIOTECE NAUKOWEJ PAU I PAN W KRAKOWIE
}

Na pogrzebie ks. Jana Ambrożego Wadowskiego, który odbył się w Lublinie 27 maja 1907 r., ks. Jan Kureczko w mowie żałobnej powiedział o nim:

[...] był to prawdziwie uczony człowiek. Był on chodzącą encyklopedyą, a w rzeczach historycznych jedną z głównych powag. Naukę zaś traktował nie jako sztukę dla sztuki, ale jako dar Boży, jako dzieło mozolnej swej pracy, obracał na korzyść kraju i Kościoła. W tym celu przeglądał archiwa, szperał w bibliotekach, kościołach; oczyszczał z kurzu różne zabytki z przeszłości, chronił od zniszczenia rozmaite papiery, książki, kartki nawet. Nad każdą rzeczą, godną uwagi, robił notatki, przepisywał manuskrypta, robił z nich wyciągi. A wszystko to czynił z taką sumiennością, że doprawdy historyk, dzięki tej literackiej spuściźnie po nim w wielu rzeczach będzie miał ułatwioną pracę ${ }^{1}$.

Istotnie, ks. J. Wadowski był historykiem który co prawda nie wydał zbyt wielu prac drukiem, ale za to pozostawił bogatą spuściznę rękopiśmienną, służącą mu w pracy jako warsztat badawczy. Spuścizna ta została przekazana Akademii Umiejętności w Krakowie w 1909 r. przez Antoniego Wadowskiego. Niestety, okoliczności przekazania tego daru jak i osoba Antoniego Wadowskiego nie są znane. Być może ofiarodawca był bratem ks. J. Wadowskiego, którego ks. J. Kureczko wymienił w mowie pogrzebowej, lub może bratankiem².

Materiały naukowe ks. J. Wadowskiego znajdują się do dnia dzisiejszego w zbiorach rękopiśmiennych Bibliotek Naukowej PAU i PAN w Krakowie. Ogółem spuścizna obejmuje 90 sygnatur w 100 woluminach. Skatalogowana została dopiero po II wojnie światowej. Nadano jej sygnatury: 2335-2392, 3259-3279 oraz 12 836-12 846. Ta pierwsza część jest opisana w Katalogu rękopisów Biblio-

* Ewa Danowska - dr hab. historii, starszy kustosz dyplomowany w Bibliotece Naukowej PAU iPAN w Krakowie, e-mail: ewa.lidia.danowska@gmail.com

${ }^{1} \mathrm{~J}$. Kureczko, Mowa żałobna miana na pogrzebie ś.p. ks. prałata kapituly zamojskiej Jana Ambrożego Wadowskiego w Lublinie 27 maja 1907 r. [...], Lublin 1907, s. 11-12.

${ }^{2}$ Tamże, s. 16. 
teki PAN w Krakowie. Liczy 58 sygnatur w 62 woluminach, bowiem sygnatura 2370 podzielona została na dwa tomy, natomiast sygnatura 2387 - na cztery. Podział spowodowany był obszernością materiału, a zarazem jego jednorodnością ${ }^{3}$. Opis kolejnej części spuścizny ks. J. Wadowskiego zamieszczono w następnym Katalogu rękopisów Biblioteki PAN w Krakowie. Ta część jego materiałów podzielona została na 21 jednostek sygnaturowych, obejmujących 27 woluminów ${ }^{4}$. Natomiast nie objęta jeszcze katalogiem drukowanym pozostała część spuścizny ks. J. Wadowskiego, która niedawno została skatalogowana, a jej opis znajduje się w katalogu kartkowym. Jak już wspomniano, obejmuje przedział sygnatur 12 836-12 846, czyli 11 jednostek sygnaturowych. Proweniencję określono: $Z$ papierów J. A. Wadowskiego. Materiały te wpisano do księgi inwentarzowej dopiero w 2012 r. Jest to odnaleziona w magazynach podczas przeprowadzki, z pewnością już ostatnia część spuścizny przekazanej przez A. Wadowskiego w 1909 r.

Jan Ambroży Wadowski urodził się 26 sierpnia 1839 r. w Kamionce w powiecie lubartowskim, w rodzinie chłopskiej. Był synem Tomasza i Marianny z domu Drozd vel Drozdowskiej. Według aktu urodzenia otrzymał tylko imię Jan, natomiast drugie - Ambroży, przybrał dopiero w zakonie. Pierwsze nauki pobierał w szkółce elementarnej w Kamionce, a potem uczył się prywatnie. We wrześniu 1855 r., w wieku 16 lat, wstąpił do zakonu dominikanów w Lublinie, a w lutym 1857 r. złożył uroczyste śluby zakonne. Od początku pobytu w lubelskim klasztorze, przez około 5 lat słuchał wykładów w zakonnym studium, w zakresie odpowiadającym seminarium duchownemu. Święcenia kapłańskie przyjął z rąk bpa lubelskiego ks. Wincentego Pieńkowskiego w 1862 r., a następnie został wysłany do Akademii Rzymsko-Katolickiej w Warszawie. W 1865 r. ukończył Akademię ze stopniem kandydata św. teologii.

W 1865 r. zamieszkał na kilkanaście miesięcy w klasztorze w Gidlach k. Częstochowy, słynącego z cudownej figury Matki Boskiej. Należy nadmienić, że po kasacie zakonów w Królestwie Polskim w 1864 r., dwa lata później J. Wadowski przeszedł do duchowieństwa diecezjalnego. Władze rządowe nie pozwoliły mu na pobyt $\mathrm{w}$ diecezji lubelskiej, osiadł więc w diecezji kujawsko-kaliskiej. Na początku 1867 r. objął funkcję wikariusza przy katedrze we Włocławku, którą łączył przez cztery lata $\mathrm{z}$ obowiązkami profesora historii Kościoła w tamtejszym seminarium duchownym. Ks. J. Wadowski od $1871 \mathrm{r}$. starał się o przeniesienie, z powodów rodzinnych, do Lublina. Stało się to dopiero w 1877 r. 15 czerwca został wikariuszem przy katedrze lubelskiej. Do 1884 r. uczył w seminarium duchownym, a także był sekretarzem konsystorza. Od 1885 r. pełnił funkcję proboszcza w Bystrzycy, a od 1895 r. - w Abramowicach koło Lublina. Uzyskał również godność kanonika kolegiaty zamojskiej.

Według niektórych badaczy (Franciszek Stopniak, Jerzy Starnawski) ks. J. Wadowski został usunięty przez władze rosyjskie z probostwa w Abramowicach, za zorganizowanie pielgrzymki do Częstochowy w $1903 \mathrm{r}$.

${ }^{3}$ Katalog rękopisów Biblioteki PAN w Krakowie. Sygnatury 2299-2630, oprac. Z. Jabłoński, A. Preissner i B. Schnaydrowa, Wrocław-Warszawa-Kraków 1967, s. 36-80.

${ }^{4}$ Katalog rękopisów Biblioteki PAN w Krakowie. Sygnatury 2907-3606, oprac. J. Dużyk, B. Schnaydrowa, red. Z. Jabłoński, Wrocław-Warszawa-Kraków-Gdańsk 1973, s. 100-121. 
Następnego roku, czyli w 1904 powrócił do Lublina, gdzie otrzymał stanowisko wikariusza-rektora pokapucyńskiego kościoła pw. śś. Piotra i Pawła. Na dwa miesiące przed śmiercią, która nastąpiła 24 maja 1907 r., został podniesiony do godności prałata kapituły kolegiaty zamojskiej. Należy dodać, że pochowany został w Lublinie, na cmentarzu przy ul. Lipowej, a w kościele parafialnym w Bystrzycy, gdzie był proboszczem, wmurowano poświęconą mu tablicę pamiątkową ${ }^{5}$ Można nadmienić, że ks. J. Wadowski zmarł w kilkanaście miesięcy po zgonie innego słynnego lublinianina - Hieronima Łopacińskiego ${ }^{6}$.

Ks. J. Wadowski przez dziesięciolecia dokonywał odpisów interesujących go materiałów archiwalnych, robił wypisy i notatki. Zauważyć należy także w jego spuściźnie istnienie wielu oryginalnych dokumentów, które zapewne zdobywał zwyczajem dziewiętnastowiecznych historyków, wydobywając z zapomnianych miejsc w klasztorach, czy kościołach. W ten sposób archiwalia, do których nie przywiązywano żadnej wagi, a tym bardziej starania, zostały ocalone i wykorzystane do pracy naukowej. Ks. J. Wadowski był osobą znaną z naukowych zainteresowań i zamiłowania do pamiątek przeszłości. Przesyłano mu zatem archiwalia, które wykorzystywał w swej pracy. Jako przykład i poparcie tej tezy, można zacytować zachowany list do niego, od ks. Jana Olszańskiego:

Wielmożny Xięże Kanoniku Dobrodzieju,

Ochraniając od zniszczenia kilka dawnych szpargałów, posyłam je na własność WMPanu Dobrodziejowi, jako mogące mieć wartość naukową dla historyka, a bagatelne dla Jego współbrata i sługi, Xiędza Jana Olszańskiego, proboszcza z Turob.[ina].

Turobin, dnia 30 września 1883.

Poniżej znajduje się adnotacja ks. Wadowskiego: „pisał to do mnie, posyłając mi kilka przywilejów Włocławka"7.

Pierwszy w kolejności skatalogowany w Bibliotece Naukowej PAU i PAN rękopis z jego spuścizny stanowią archiwalia związane z klasztorem św. Brygi-

${ }^{5}$ Własnoręczny życiorys J. A. Wadowskiego, Bibl. im. H. Łopacińskiego w Lublinie, rkps 2253, k. 1; Wadowski Jan Ambroży, w: Podręczna Encyklopedia Kościelna, t. 41-42, oprac. J. i R. Archutowskich, Warszawa-Lublin-Łódź 1915, s. 82; M. Domański, Wadowski Jan Ambroży, w: Stownik biograficzny miasta Lublina, t. 1, red. T. Radzik, J. Skarbek, A.A. Witusik, Lublin 1993, s. 281; J. Starnawski, Sylwetki lubelskich humanistów XIX i pierwszej połowy XX wieku, Lublin 2004, s. 31; A. Grychowski, Lublin i Lubelszczyzna w życiu i twórczości pisarzy polskich od średniowiecza do 1968 r., Lublin 1974, s. 254; F. Stopniak, Z działalności naukowej ks. Jana Ambrożego Wadowskiego kanonika zamojskiego, „Wiadomości Diecezjalne Lubelskie”, 34 (1960) s. $54,57$.

Znajdujemy wiadomość, że J.A. Wadowski był synem burmistrza, potem skarbnika w Kamionce, co nie wydaje się prawdą w świetle najbardziej wiarygodnego źródła, jakim jest jego własnoręcznie napisany życiorys, zob. F. Stopniak, Wadowski Jan Ambroży, w: Stownik polskich teologów katolickich, t. 7 red. H.E. Wyczawski OFM, Warszawa 1983, s. 376.

${ }^{6}$ Łopaciński zmarł w Lublinie 25 sierpnia 1906 r. R. Bender, Łopaciński Hieronim Rafat, w: Polski Słownik Biograficzny (dalej: PSB), t. 18, Wrocław-Warszawa-Kraków-Gdańsk 1973, s. 394396.

${ }^{7}$ Biblioteka Naukowa PAU i PAN w Krakowie (dalej: Bibl. Nauk. PAU i PAN), rkps 7935, k. 25-26. 
dy przy kościele Marii Panny w Lublinie. Oprawiony w skórę, zawiera spis zakonnic od 1596 do 1870 r., zapoczątkowany po wizytacji kardynała Jerzego Radziwiłła, biskupa krakowskiego, przez Agnieszkę Iastkowską, ksienię klasztoru. W tomie tym znajdują się ponadto bieżące zapiski klasztorne, takie jak np. biogramy znaczniejszych zakonnic zmarłych w latach 1622-1732, wykaz zakonnic i panien świeckich, które zginęły w czasie pożaru klasztoru w 1732 r., losy tego zgromadzenia w Brześciu, Lwowie, Łucku i Sokalu w czasie wojen kozackich 1648-1649, wzmianki o pożarach w klasztorze w latach 1732-1736, czy relacja o ewakuacji lubelskiego klasztoru brygidek do Warszawy ${ }^{8}$. Inny oryginalny rękopis, sporządzony w latach 1610-1724 zawiera historię powstania klasztoru karmelitów bosych pw. Św. Ducha w Lublinie, zapiski kronikarskie tegoż zakonu z lat 1622-1724, gdzie znajdują się podpisy braci zakonnych. Karta tytułowa rękopisu zawiera wyobrażenie Góry Karmel, iluminowane piórkiem, a oprawa skórzana pochodzi z XVII wieku9. Wiadomości o karmelitach bosych w Lublinie można zaczerpnąć także i z innego rękopisu, gdzie znajduje się kronika zakonu z lat 1728-1863, akt sprzedaży spalonego budynku klasztoru na publicznej licytacji w 1807 r. Józefowi Stadlerowi, spis zakonników sporządzony w 1817 r., krótka historia fundacji kościoła i konwentu karmelitów bosych w Lublinie z 1816 r., a także relacje i wypisy $z$ akt dotyczących utworzenia i dziejów prowincji litewskiej pw. św. Kazimierza oraz jej związków z konwentami w Lublinie i Poznaniu w latach $1737-1762^{10}$. Karmelitanek bosych w Lublinie dotyczy kolejny rękopis, oprawiony w skórę, posiadający pieczęcie odciśnięte na papierze lub czerwonym laku. Zawiera on księgę wizytacji tego klasztoru z wpisami z lat 1650-1824, ponadto różnorodne zapiski, m.in. spis dzieł należących prawdopodobnie do biblioteki klasztornej, sentencje natury religijnej, a ponadto adnotacje odnoszące się do czasu powstania i zawartości tej księgi ${ }^{11}$.

Cały szereg kolejnych woluminów ze spuścizny ks. J. Wadowskiego stanowią rękopisy jego prac, a przy nich często wypisy źródłowe i notatki. Są to kolejno: Kościót pod wezwaniem świętych Jana Chrzciciela i Jana Ewangelisty, dawniej oo. Jezuitów, dziś katedralny w Lublinie. Rys historyczny, Kościót i klasztor oo. Trynitarzów w Lublinie oraz kościót i klasztor Bonifratrów w Lublinie, Szkice do historii kościołów i klasztorów lubelskich (tu: kościół pw. Nawrócenia św. Pawła Apostoła z klasztorem bernardynów, kościół pw. św. Antoniego z Padwy, św. Franciszka, św. Wawrzyńca, Walentyna i Sebastiana Męczenników, kościół pw. św. Kazimierza z klasztorem reformatów i kościół pw. Apostołów Piotra i Pawła z klasztorem kapucynów). Następnie poszczególne tomy, o objętości 1155 kart każdy, poświęcone zostały opracowaniu poszczególnych lubelskich kościołów, a mianowicie: Kościót św. Krzyża za murami z klasztorem oo. Obserwantów, Kościót Św. Ducha, niegdyś prepozytura z szpitalem, dziś filialny, na Krakowskim Przedmieściu, Kościót p.w. NMPanny Wniebowzięcia z klasztorem najprzód Brygidek, potem Wizytek, Kościót Nawiedzenia NMPanny z klasztorem

\footnotetext{
${ }^{8}$ Tamże, rkps 2335.

${ }^{9}$ Tamże, rkps 2336.

${ }^{10}$ Tamże, rkps 2338.

${ }^{11}$ Tamże, rkps 2337.
} 
pp. Wizytek, Kościół p.w. św. Agnieszki wraz z klasztorem oo. Augustianów, dziś parafialny, na przedmieściu Kalinowszczyzna, I. Rezydencja ks.ks. Pijarów w Lublinie. II. Kościót czyli kaplica cmentarna p.w. P. Jezusa Ukrzyżowanego, Kościół unicki czyli cerkiew Świętospaska albo Przemienienia Pańskiego, Kościót Trójcy Przenajświętszej na Zamku, Kościót św. Michała parafialno-kolegiacki, Kościót św. Mikołaja na przedmieściu lubelskim «Na Czwartku» zwanym, Kościót św. Wojciecha wraz z szpitalem, Kościoły z klasztorami zakonu Karmelickiego (tu: NMP Szkaplerznej wraz z klasztorem Karmelitów Bosych na Krakowskim Przedmieściu, kościół pw. św. Józefa Oblubieńca NMP i św. Teresy z klasztorem karmelitanek bosych, kościół Niepokalanego Poczęcia NMP wraz z klasztorem karmelitanek bosych, dziś szpital szarytek, kościół pw. Eliasza Proroka z klasztorem oo. Karmelitów antiqua observantiae, później Bonifratrów na Krakowskim Przedmieściu $)^{12}$. Z kolei kościołowi św. Piotra księciu Apostołów z klasztorem zakonnic 3. reguły św. Franciszka czyli Bernardynek zostało poświęcone dwutomowe opracowanie wraz z chronologicznym wykazem przeorysz tego klasztoru od 1618 do 1879 r. $^{13}$ Do zbioru opracowań dotyczących placówek kościelnych Lublina zalicza się też wolumin Kościót św. Jana Chrzciciela $i$ św. Jana Ewangelisty, dawniej ks. Jezuitów, dziś katedralno-parafialny ${ }^{14}$. Kolejny wolumin, zatytułowany Kościoły w Lublinie i diecezji lubelskiej podzielony został przez ks. J. Wadowskiego na trzy tomy, a opisane zostały tam kościoły w poszczególnych dekanatach diecezji lubelskiej, opatrzone indeksem nazw miejscowości, kościołów i kaplic. Natomiast spośród lubelskich kościołów zawarte są tu opisy: Św. Trójcy na Zamku lubelskim, św. Michała Archanioła przy ul. Grodzkiej i kościół św. Mikołaja na Czwartku. Znajdujemy tu także spisy kościołów i prac im poświęconych. Inny z rękopisów z omawianej spuścizny zawiera zbiór kopii dokumentów i notat, np. do dziejów kościoła św. Mikołaja na Czwartku w Lublinie. Kopie pochodzą z XVIII wieku, a są to m.in. wykaz czynszów z $1694 \mathrm{r}$. z realności położonych na gruntach kościelnych, sumariusz dokumentów zestawiony w 1783 r., czy zestawienia akt wójtowskich i ławniczych z lat 1619-168015. Lublina dotyczy także tom Znakomitsze osoby $w$ dziejach Lublina na wzmiankę zastugujace sposobem abecadtowym spisane, gdzie znajdujemy kilkadziesiąt nazwisk ze skromnymi danymi biograficznymi ${ }^{16}$. Jako szczególnie cenną można uznać oryginalną Księgę protokołów zebrań konwentu oraz wizytacji klasztoru i szpitala Bonifratrów Bożego Ciała w Lublinie z lat 1720-175317, a także Księge wydatków bractwa różańcowego przy kościele Dominikanów w Wysokim Kole z lat 1825-1865 ${ }^{18}$. Kolejne dwa zbiory notat i kopii dokumentów zebranych przez ks. Wadowskiego dotyczą dziejów kościoła św. Michała Archanioła i kościoła Św. Trójcy w Lublinie ${ }^{19}$. Kilka

\footnotetext{
${ }^{12}$ Tamże, rkps 2349-2354, 2356-2364.

${ }^{13}$ Tamże, rkps 2370, t. 1-2.

${ }^{14}$ Tamże, rkps 2371.

15 Tamże, rkps 2376.

16 Tamże, rkps 2385.

${ }^{17}$ Tamże, rkps 2389.

${ }^{18}$ Tamże, rkps 2390.

${ }^{19}$ Tamże, rkps 2377-2378.
} 
kolejnych woluminów dotyczy klasztoru dominikanów w Lublinie, co nie powinno dziwić, gdyż jak zostało wspomniane, ks. J. Wadowski swą służbę Kościołowi rozpoczął w tamtejszym klasztorze dominikanów. Są to oryginalne dokumenty z XVII-XVIII wieku i odpisy wcześniejszych. Dotyczą one spraw majątkowych, kontrakty i inwentarze, znajdujemy też akta sądowe, rozporządzenia, zapisy, itp. ${ }^{20}$ W jednym z woluminów znajduje się Sumariusz dokumentów majątkowych klasztoru Dominikanów w Lublinie z XVII-XVIII wieku ${ }^{21}$. Własności tego klasztoru dotyczą również dokumenty z lat 1570-1751 odnoszące się do wsi Mętów i Ćmiłów, należących do dominikanów - sumariusze dokumentów do spraw majątkowych czy inwentarze ${ }^{22}$. Oryginalne dokumenty dotyczące tego klasztoru z lat 1517-1861 znajdują się w kilku kolejnych tomach, a są to akty nadania, przywileje, testamenty, akta majątkowe czy listy ${ }^{23}$. Ogólnie klasztorów dominikańskich w Polsce w latach 1620-1780 dotyczy ostatni z tomów, zawierający uwierzytelnione kopie i inne odpisy akt odnoszących się głównie do spraw majątkowych klasztorów w poszczególnych miejscowościach, usystematyzowanych alfabetycznie ${ }^{24}$. Warto też zwrócić uwagę na Materiaty historyczne z lat 1801-1823 dotyczace diecezji lubelskiej, gdzie są kopiariusze rozporządzeń władz cywilnych i wojskowych Królestwa Polskiego przekazanych diecezji lubelskiej, czy m.in. listy pasterskie biskupa Wojciecha Skarszewskiego ${ }^{25}$. Głównie do Lublina odnoszą się Materiaby z lat 1508-1779 dotyczace kościelnych spraw majatkowych - kontrakty, akta procesowe, majątkowe różnych klasztorów, a także kościoła unickiego ${ }^{26}$. Warto też zwrócić uwagę na oryginalne Regesty dokumentów klasztoru Bazylianów $w$ Lublinie z XVII i XVIII wieku ${ }^{27}$. Materiały tu zawarte zostały wykorzystane przez ks. Wadowskiego przy opracowaniu Kościołów lubelskich, wydanych drukiem w Krakowie w 1907 r., nakładem Akademii Umiejętności ${ }^{28}$.

Należy odnotować obecność w spuściźnie kolejnej pracy ks. J. Wadowskiego, tym razem z dziedziny bibliologii: Manuskrypta Biblioteki Seminaryjnej w Lublinie $^{29}$. Przy okazji trzeba wspomnieć, że Wadowski zainteresował się również księgozbiorem byłego klasztoru kanoników regularnych lateraneńskich w Kraśni$\mathrm{ku}$, znajdując tam interesujący go rękopis, z którego kopię sporządził w $1881 \mathrm{r}$., opatrując uwagami: „Antiquissime constitutiones synodales provinciae Poloniae seu Gnesnensis" ${ }^{30}$.

Warto też zwrócić uwagę na Dokumenty z lat 1649-1798 dotyczace miasta Lublina i województwa lubelskiego. Są tam bowiem materiały polityczne: lauda

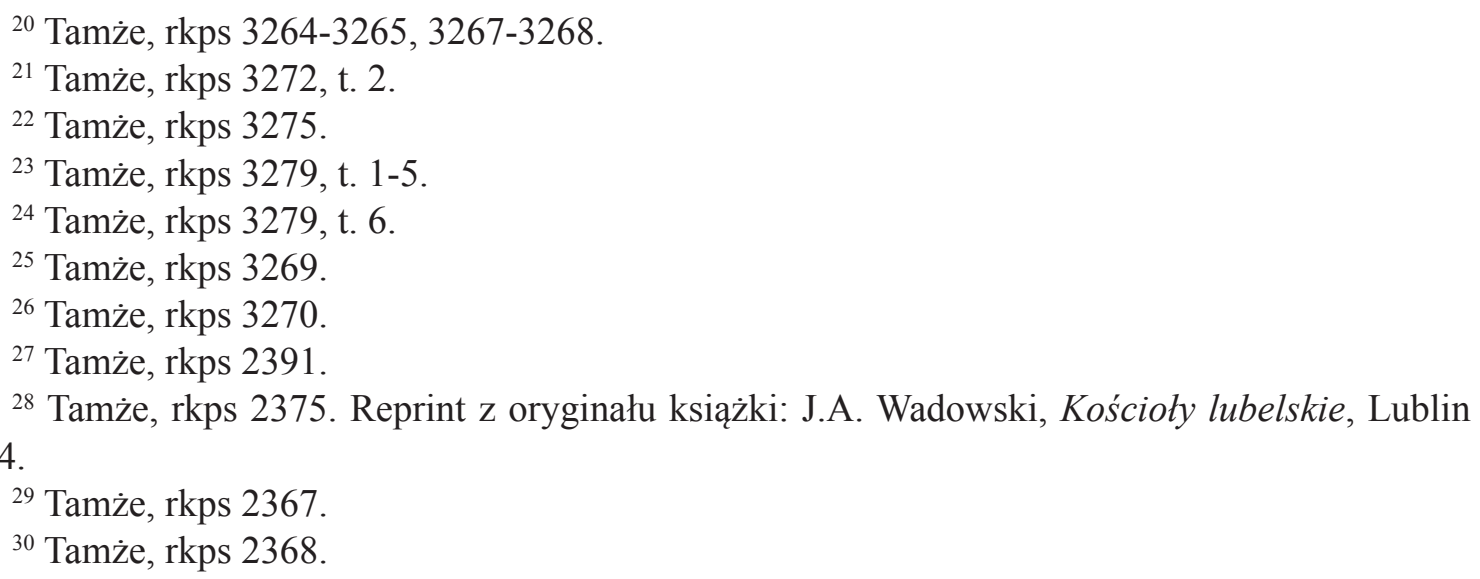

${ }^{30}$ Tamże, rkps 2368. 
sejmikowe, akta odnoszące się do spraw wojskowych i podatkowych, papiery gospodarcze, w tym cechowe $\mathrm{i}$ inne ${ }^{31}$. Ks. J. Wadowski zachował w rękopisach swe prace dotyczace m.in. Lubelszczyzny, a mianowicie: Dzieje diecezji lubelskiej oraz Dzieje diecezji chetmskiej i lubelskiej ${ }^{32}$.

Spuścizna ks. J. Wadowskiego nie zawęża się jednak do Lublina, jego dziejów i placówek kościelnych. Zachowały się również materiały dotyczące innych miast, którym uwagę ten badacz poświęcał. Kilka z woluminów wiąże się z Zamościem. Niektóre z zachowanych rękopisów ks. J. Wadowski podał do druku, jak np. Anacephaleosis professorum Academiae Zamoscensis. Wiadomość o profesorach Akademii Zamojskiej. Rękopis z XVII w. ${ }^{33}$ Zamościa dotyczą dwa kolejne woluminy: Dzieje Akademii Zamojskiej - fragment rozprawy, ponadto notaty z wiadomościami dotyczącymi m.in. biblioteki i archiwum Akademii, czy jej drukarzy. Do Zamościa odnosi się też zbiór kopii, regestrów i opisów głównie bull papieskich i nadań monarszych od XVI do XVIII wieku ${ }^{34}$. Do dziejów Akademii Zamojskiej, ordynacji czy kolegiaty, ks. J. Wadowski zebrał dokumenty pochodzące od XVI do XVIII wieku. Są to m.in. listy różnych osób do różnych adresatów, bulle papieskie, dokumenty królewskie Michała Korybuta Wiśniowieckiego, Jana III Sobieskiego, Augusta II Mocnego Sasa i Augusta III Sasa, liczne akta majątkowe, testamenty zawierające legaty na rzecz Akademii Zamojskiej, skrypty dłużne, różne dekrety władz kościelnych i wyższego duchowieństwa, memoriały, dokumenty rozmaitej treści, m.in. prawne ${ }^{35}$. W kolejnych tomach tej samej sygnatury znajdujemy inwentarz kościoła św. Tomasza Apostoła z 1802 r. oraz zbiór innych inwentarzy m.in. kolegiaty zamojskiej ${ }^{36}$. Nie odbiega zawartością od poprzednio wymienionych, kolejny tom Zbiór dokumentów z XV-XIX w. dotyczacych Akademii, kolegiaty i ordynacji zamojskiej. Są to listy różnych osób do różnych adresatów, dekrety w sprawie reformy kolegiaty zamojskiej, rozporządzenia i inne akta majątkowe ordynacji, a także materiały o różnej treści, w tym teksty literackie ${ }^{37}$. Zamościa dotyczy następny rękopis, koncentrujący się na sprawach miasta w latach 1750-1751, takich jak np. inwentarze ratusza i izby radzieckiej, wadze miejskiej, łaźni czy browarze. Ponadto zachowały się tu comiesięczne zapisy przychodów i wydatków miasta, roczne sumariusze wpływów pogłównego, czynszu z jatek, czy dochodów z browaru ${ }^{38}$. Kolejny rękopis ze zbioru ks. J. Wadowskiego pochodzi z 1842 r. i zawiera rys historyczny kolegiaty zamojskiej sporządzony przez ks. Joachima Jędrzejewicza, kanonika honorowego tejże kolegiaty, plebana w Rachaniach. Praca ta obejmuje statuty kolegiaty, dane dotyczące jej założenia przez Jana Zamoyskiego oraz fundacji poszczególnych kaplic i kanonii,

${ }^{31}$ Tamże, rkps 3278.

${ }^{32}$ Tamże, rkps 2365-2366.

${ }^{33}$ Tamże, rkps 2369. Zob. A. Wadowski, Materiaty i opracowania dotyczace historii wyższych zakładów naukowych w Polsce, t. 1, Warszawa 1899-1900.

${ }^{34}$ Bibl. Nauk. PAU i PAN, rkps 2383-2384.

${ }^{35}$ Tamże, rkps 2387 t. 1-2.

${ }^{36}$ Tamże, rkps 2387, t. 3-4.

${ }^{37}$ Tamże, rkps 3274.

${ }^{38}$ Tamże, rkps 2341. 
spis praw, przywilejów i obowiązków kapituły, a także i inne wiadomości historyczne związane z dziejami Zamościa i członkami rodu Zamoyskich ${ }^{39}$. Kolegiaty zamojskiej, w latach 1859-1864 dotyczy także kolejny rękopis. Jest to rozprawa nieznanego autora, z adnotacjami ks. J. Wadowskiego, a dotyczy dziejów Zamościa, wspomnianej kolegiaty św. Tomasza, seminarium duchownego, zamojskich kościołów i klasztorów oraz Akademii Zamojskiej ${ }^{40}$.

Inne rękopisy dotyczą miejscowości i spraw innych miast, poza Lublinem i Zamościem. W spuściźnie ks. J. Wadowskiego znajdujemy: Kopiariusz i zbiór akt konwentu Pijarów w Opolu Lubelskim z lat 1744-1810, a w nim dekrety i orędzia hierarchów Kościoła związane z działalnością pijarów, rozporządzenia, przepisy i listy władz naczelnych i prowincjonalnych tego zakonu. Ponadto $\mathrm{w}$ tomie tym znajdują się m.in. uchwały polskich kapituł prowincjonalnych, adnotacje dokonane z okazji wizytacji klasztoru przez wizytatorów polskiej prowincji. Rękopisy uzupełnione są drukami, takimi jak brevia i encykliki papieskie, dekrety kurii rzymskiej odnoszące się do kanonizacji i kultu św. Józefa Kalasantego, rozporządzenia generałów zakonu pijarów, a także prowincjałów polskich, czy statuty ${ }^{41}$. W zbiorze ks. J. Wadowskiego znajduje się również katalog księgozbioru pijarów w Opolu Lubelskim, podzielony na 19 działów, pochodzący z lat 1798-180142.

Warto również zwrócić uwagę na Protokół cyrkularzów [...] Urzędu Cyrkułu Józefowskiego, zaczynający się 7 czerwca 1792 r., a kończący się 7 lipca 1799 r. Znajdujemy tam pełne teksty, daty i numery zarządzeń kierowanych przez Urząd Cyrkularny w Józefowie do dominiów, magistratów, urzędów parafialnych i kahałów znajdujących się w obrębie tego cyrkułu, w sprawach ogólno-administracyjnych, gospodarczych, demograficznych, handlowych, karno-sądowych, kulturalno-oświatowych, wojskowych i innych. Wolumin ten zawiera również szczegółowy indeks powyższych okólników ${ }^{43}$.

Inny rękopis zawiera Akta Seminarium Zgromadzenia Misjonarzy św. Wincentego á Paulo w Domu Św. Krzyża w Warszawie. Jest on stosunkowo niezbyt obszerny, sporządzony w latach 1781-1811, a zawiera m.in. zarządzenia regulaminowe biskupa Antoniego Onufrego Okęckiego, imienne wykazy alumnów i roczne zestawienia refundacji kosztów ich utrzymania, czy protokół o stanie funduszy seminaryjnych ${ }^{44}$.

Nie tylko Lubelszczyzny dotyczy też Księga zawierajaca $w$ sobie rozporzadzenia władz duchownej i cywilnej, dotycząca lat 1805-1866. Obejmuje ona listy pasterskie i zarządzenia władz diecezjalnych lubelskich, a także rozporządzenia władz cywilnych i wojskowych Królestwa Polskiego przekazywanych diecezji lubelskiej do wiadomości i rozpowszechniania. Z zachowanej zapiski wynika, że księga należała do parafii zamojskiej, a darowana została ks. J. Wadowskiemu w 1875 r. przez ks. Józefa Szumilaka, wikariusza kościoła w Dysie ${ }^{45}$.

\footnotetext{
${ }^{39}$ Tamże, rkps 2344.

${ }^{40}$ Tamże, rkps 2345.

${ }^{41}$ Tamże, rkps 2339.

${ }^{42}$ Tamże, rkps 2340.

${ }^{43}$ Tamże, rkps 2342.

${ }^{44}$ Tamże, rkps 2343.

${ }^{45}$ Tamże, rkps 2346.
} 
Za ciekawostkę można uznać rękopis: Odpowiedź Jaśnie Wielmożnego Kobielskiego biskupa tuckiego przeciwko Żydom, pochodzący z XVIII wieku. Zawiera on treść dysputy religijnej pomiędzy biskupem Franciszkiem Antonim Kobielskim a członkami synagogi $\mathrm{w}$ Brodach, czyli zastrzeżenia wysunięte przez synagogę przeciwko tezom kazania biskupa, jego replikę a wraz z nią wykaz tekstów biblijnych ${ }^{46}$.

Jak wynika z zachowanego tomu ze zbiorów ks. J. Wadowskiego, interesował się on też historią Polski, zachowując kopie dokumentów politycznych w tym zakresie, pochodzących z lat 1762-1770. Znajdujemy tam m.in. diariusz zerwanego sejmu walnego warszawskiego z 1762 r. zawierający spis posłów, manifesty i listy, jak również diariusz obrad senatu z 1762 r., przy tym poczet senatorów, mowy i propozycje od tronu. Jest także diariusz sejmu z 1763 r., a także materiały do dziejów konfederacji barskiej i inne drobniejsze dokumenty ${ }^{47}$. Są również oryginalne Miscelanea historyczne z lat 1667-1774 dotyczące spraw politycznych kraju, lauda sejmikowe, uniwersały, sumariusze wydatków ${ }^{48}$. Z tomem tym wiążą się tematycznie następne, a jest to: Zbiór kopii dokumentów do dziejów Polski z lat 1635-1820 - materiały polityczne, wojskowe, sejmowe, czy dotyczące historii Kościoła oraz Zbiór kopii dokumentów politycznych do historii Polski z lat 16831768 , gdzie są różnego rodzaju listy, manifesty, memoriały i mowy ${ }^{49}$.

Znajdujemy także fragment jego rozprawy zatytułowanej Treść dziejów Kościoła katolickiego $w$ Polsce, a przy niej biografię ks. Piotra Ściegiennego ${ }^{50}$. Wspomnieć należy, że ks. J. Wadowski interesował się nie tylko historią polityczną, bowiem w dwóch woluminach znajdziemy oryginalne testamenty z XVI, XVII i XVIII wieku, ponadto fragmenty papierów majątkowych różnych osób i kilka listów ${ }^{51}$. Rodziny Orzechowskich dotyczy wolumin zawierający zbiór dokumentów z lat 1618-1776: papiery majątkowe i sądowe. Inny z tomów zawiera Summariusz dokumentów majątkowych rodziny Orzechowskich z XVI-XVIII wiek $u^{52}$. O zainteresowaniach ks. J. Wadowskiego genealogią świadczy inny z woluminów: Zbiór do genealogii różnych rodzin polskich, gdzie są m.in. tablice genealogiczne ${ }^{53}$. Znajdujemy też Summariusz dokumentów majątkowych rodzin Betzeckich $i$ Łuszczewskich z XVII-XVIII wieku ${ }^{54}$, a także zawarte w dwóch woluminach materiały z XVII-XVIII wieku odnoszące się do spraw majątkowych różnych osób, ujętych w kolejności alfabetycznej, a są to umowy, zapisy, listy, akta sądowe, inwentarze i wiele innych archiwaliów ${ }^{55}$. Sumariusze dokumentów od XV do XVIII wieku znajdujemy też pod inną sygnaturą, a dotyczą one z kolei

\footnotetext{
${ }^{46}$ Tamże, rkps 2347.

${ }^{47}$ Tamże, rkps 2348.

${ }^{48}$ Tamże, rkps 3259.

${ }^{49}$ Tamże, rkps 3260-3261.

${ }^{50}$ Tamże, rkps 2355.

${ }^{51}$ Tamże, rkps 3262-3263.

${ }^{52}$ Tamże, rkps 3266, 3272 t. 1.

${ }^{53}$ Tamże, rkps 2388.

${ }^{54}$ Tamże, rkps 3273

${ }^{55}$ Tamże, rkps 3276-3277.
} 
miejscowości: Bątki, Bełżyce, Borów, Chmielnik, Łubki, Maszki, Miłocin, Nałęczów, Palkije, Podole, Przedmieście, Szczuki, Wojciechów, Wola Wojciechowska i Wzgórze ${ }^{56}$. Można też nadmienić o istnieniu innego woluminu, gdzie są, wypisy źródłowe, notaty, biografie różnych osób, a przy tym opracowanie $O$ wypetnianiu obowiazków przez kapłanów ${ }^{57}$.

Diecezji chełmskiej zostały poświęcone trzy kolejne woluminy ze spuścizny ks. J. Wadowskiego. Są to: Dzieje dawnej diecezji chetmskiej i jej kościołów wraz z alfabetycznym wykazem miejscowości, w których znajdują się kościoły parafialne, filialne, szpitalne, kaplice publiczne i niektóre prywatne ${ }^{58}$. Ks. J. Wadowski zgromadził także kopie dokumentów odnoszących się do kościołów diecezji chełmskiej od XIV do XVIII wieku, zaopatrzone w indeks, spisy dokumentów i adnotacje. Jest to zbiór pokaźny, gdyż liczący 1176 stron $^{59}$. Wiąże się z nim tematycznie następny rękopis: Zbiór wypisów źródłowych do dziejów diecezji chetmskiej, zawierający kopie dokumentów i oryginały, jak obszerna relacja o przebiegu kasaty kościoła i klasztoru bernardynów w Radecznicy, a także liczne imienne spisy hierarchii duchownej różnych obrządków. Ponadto w tomie tym znajduje się fragment pracy ks. J. Wadowskiego Kościoły dawnej diecezji przemyskiej, obecnie w obrębie diecezji lubelskiej, zawierający dzieje kościołów w Tarnobrzegu, Potoku, Krzeszowie, Hucie Krzeszowskiej i Łukowej ${ }^{60}$. Warto też zwrócić uwagę na rękopis: Materiały do życiorysów biskupów chetmskich, gdzie znajdują się ich biogramy w kolejności alfabetycznej ${ }^{61}$.

Diecezji chełmskiej i lubelskiej dotyczą dwa kolejne rękopisy, gdzie ks. J. Wadowski zamieścił spisy i regestry dokumentów odnoszących się do kościołów, opisy niektórych zespołów archiwalnych, a ponadto zarys historyczny innych diecezji polskich, wypisy źródłowe i notaty, a także statut bpa Wojciecha Skarszewskiego oraz dekrety dotyczące różnowierców, a także Żydów i Cyganów ${ }^{62}$. Znajdujemy także sporządzone przez ks. J. Wadowskiego wypisy źródłowe i notaty do dziejów diecezji chełmskiej, lubelskiej, łuckiej i podlaskiej ${ }^{63}$.

Kończąc przegląd zawartości spuścizny ks. J. Wadowskiego przechowywanej w Bibliotece Naukowej PAU i PAN w Krakowie, należy nadmienić o wspomnianej na początku ostatniej części jego materiałów, czyli sygnaturach 12 83612 846. Wpisane do inwentarza i wstępnie skatalogowane zostały stosunkowo niedawno, należy też przyznać, że nie mają takiej wartości, jak omówione powyżej. Być może bibliotekarze opracowujący materiały po ks. J. Wadowskim uznali je, niesłusznie, za zbędne i odłożyli, lub też zawieruszyły się gdzieś w magazynach pośród innych rękopisów. Znajdujemy tam: brulion rozprawy dotyczącej bpa Szymona Ługowskiego (Szaniawskiego) i rodziny Szaniawskich, przy

\footnotetext{
${ }^{56}$ Tamże, rkps 3271.

${ }^{57}$ Tamże, rkps 2392.

${ }^{58}$ Tamże, rkps 2372.

${ }^{59}$ Tamże, rkps 2373.

${ }^{60}$ Tamże, rkps 2374.

${ }^{61}$ Tamże, rkps 2379.

${ }^{62}$ Tamże, rkps 2380-2381.

${ }^{63}$ Tamże, rkps 2386.
} 
tym brulion opracowania dziejów miasta i Akademii Bialskiej ${ }^{64}$. Ponadto fragment materiałów do dziejów kolegiaty zamojskiej, wypisy źródłowe i notaty do dziejów diecezji lubelskiej dotyczące duchowieństwa, pisma i listy pasterskie bpa Walentego Baranowskiego (1872-1878) oraz druki innych biskupów lubelskich ${ }^{65}$. Historyka może zainteresować inwentarz posiadłości wsi Mętowa, należącej do dominikanów w Lublinie; wypisy odnoszące się lubelskiego szpitala św. Wincentego à Paulo (1723-1726) oraz Towarzystwa Dobroczynności, czy kopie rozporządzeń bpa przemyskiego Hieronima Sierakowskiego (1746-1752 ${ }^{66}$. W tej części spuścizny są także materiały do dziejów Kościoła katolickiego w Polsce, m.in. odpisy listów pasterskich, ale także rozporządzeń władz cywilnych pochodzące z XIX wieku. Do diecezji kujawsko-kaliskiej zachowane są kopie korespondencji biskupa Michała Marszewskiego (1834-1861) i władz cywilnych ${ }^{67}$. Są także papiery ks. J. Wadowskiego dotyczące parafii i kościoła w Bystrzycy, materiały bibliograficzno-historyczne takie jak: opis wydarzeń w 1848 r. pod Trzemesznem i Wrześnią z udziałem gen. Ludwika Mierosławskiego, czy odpisy dokumentów rodzinnych Joszynów ${ }^{68}$.

Należy stwierdzić z przykrością, że nadane sygnatury podczas opracowania spuścizny w latach 60. i 70. XX wieku i ujęte w wydanych katalogach, jakkolwiek poszczególne jednostki sygnaturowe opracowane zostały poprawnie, to ich kolejność sprawia wrażenie zupełnie przypadkowego. Tematyka poszczególnych tomów jest przemieszana, brakuje logicznego układu i zwrócenia uwagi na zawartość merytoryczną poszczególnych woluminów.

Książka inwentarzowa, która zawierałaby wpis spuścizny ks. J. Wadowskiego przekazanej Bibliotece PAU w 1909 r. nie istnieje. Tym bardziej należałoby się spodziewać, że bibliotekarze nadający kolejne sygnatury i sporządzający drukowany katalog postarają się o większą staranność w segregowaniu i porządkowaniu materiału.

Celem badań ks. J. Wadowskiego było opracowanie historii diecezji lubelskiej, ale duża ilość zgromadzonego materiału archiwalnego, przekroczyła jego możliwości naukowe. W wyniku kwerend napisał historię 44 kościołów parafialnych, rektoralnych, szpitalnych i kaplic z terenu diecezji lubelskiej, a właściwie archidiakonatu lubelskiego i byłej diecezji chełmskiej69. Źródła do swych badań wyszukiwał w archiwum konsystorza lubelskiego i archiwów parafialnych, ale też korzystał z Archiwum Kurii Metropolitalnej Krakowskiej. W stosunku do ilości materiałów jakie ks. J. Wadowski zgromadził i opracował, drukiem wydał niewiele, lecz są to pozycje znaczące, nie tracące aktualności. Należy do nich Wiadomość o profesorach Akademii Zamojskiej, wydana w Warszawie 1899-1900, a także prawie sześćsetstronicowa praca Kościoły lubelskie. Na podstawie źródet

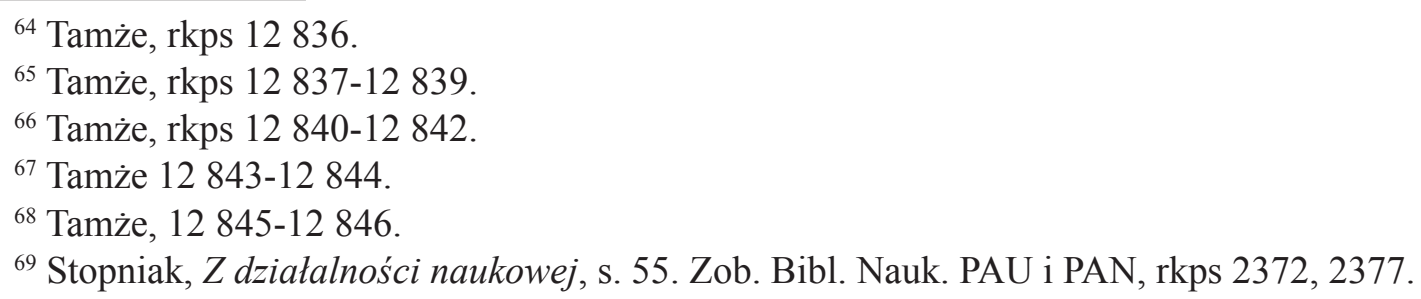


archiwalnych, wydana w Krakowie w 1907 r. ${ }^{70}$ Opublikował też liczne artykuły w 12 tomie Encyklopedii kościelnej (wyd. 1879 r.), dotyczące głównie Lublina $^{71}$. Ks. J. Wadowski był też surowym, aczkolwiek sprawiedliwym recenzentem pierwszego tomu Monografii Lublina Władysława Kazimierza Zielińskiego, wydanej w 1878 r. Po krytyce tej pracy zamieszczonej w „Przeglądzie Katolickim” w 1879 r., autor zrezygnował z publikacji kolejnych tomów ${ }^{72}$.

Współczesne mu środowisko duchowieństwa diecezji lubelskiej uznawało jego autorytet i dorobek jako historyka, o czym świadczyć może list z 26 lipca 1888 r., z nagłówkiem „Administrator Dyecezyi Lubelskiej”, podpisany nieczytelnym nazwiskiem przez kanonika katedralnego:

Pragnąc Katalog Duchowieństwa Dyecezyi Lubelskiej oczyścić z błędów jakie odnośnie do dat i nazwisk osób historycznych ostatniemi czasy do rzeczonego wydawnictwa zakradły się, a nadto zamierzając uzupełnić go wiadomościami do pierwotnej erekcyi każdego z kościołów Dyecezyi odnoszącemi się, postanowiłem dokonanie tej pracy powierzyć WKs. Kanonikowi, którego uprzejmie proszę, aby w ciągu jednego miesiąca pracę tę dokonał i takową mi nadesłał.

Dla informacyi załącza się katalog Duchowieństwa Dyecezyi Podlaskiej z roku 1862 i dla korrekty Katalog Dyecezyi Lubelskiej z roku bieżącego ${ }^{73}$.

Ks. J. Wadowski uporał się z powierzoną mu pracą, a dnia 29 sierpnia 1888 r. odesłał jej gotowy efekt z Bystrzycy, gdzie wówczas był proboszczem, do Lublina, pisząc, że dokonał ,poprawki części historycznej” i objaśniając, do czego sprowadziły się jego ingerencje ${ }^{74}$.

O ks. J. Wadowskim jako historyku, pochlebnie wyrażał się Hieronim Łopaciński, zalecając kontakt z nim w liście z 3 maja 1896 r. Teodorowi Wierzbowskiemu (1853-1923), profesorowi literatury polskiej na Uniwersytecie Warszawskim, który miał przybyć do Lublina. Wysoko cenił ks. J. Wadowskiego także historyk ks. Ludwik Zalewski (1878-1952) ${ }^{75}$. Natomiast w jednym w biogramów ks. J. Wadowskiego pojawiła się informacja, że był członkiem korespondentem Akademii Umiejętności w Krakowie ${ }^{76}$. Nie jest to zgodne z prawdą, ponieważ jego nazwisko nie figuruje w spisie członków tego gremium ${ }^{77}$. Akademia Umiejętności własnym nakładem wydała mu w 1907 r. wspomnianą książkę Kościoły lubelskie, stąd może wyniknęła ta nieścisłość.

${ }^{70}$ Stopniak, Z działalności naukowej, s. 56-57. Pełną bibliografię prac ks. J. Wadowskiego wydanych drukiem, a także pozostawionych w rękopisach, zob. Stopniak, Wadowski Jan Ambroży, s. 377-378.

${ }^{71}$ Domański, Wadowski Jan Ambroży, s. 282.

${ }^{72}$ Grychowski, Lublin, s. 228-229.

${ }^{73}$ Biblioteka im. H. Łopacińskiego w Lublinie, rkps 2253, k. 2.

${ }^{74}$ Tamże, rkps 2253, k. 3-3v.

${ }^{75}$ Starnawski, Sylwetki lubelskich humanistów, s. 32.

${ }^{76}$ Domański, Wadowski Jan Ambroży, s. 282.

77 Zob.: E.H. Nieciowa, Członkowie Polskiej Akademii Umiejętności 1872-1952, Wrocław -Warszawa-Kraków-Gdańsk 1973; „Rocznik Akademii Umiejętności w Krakowie”, 1907/1908, s. 39-41 (zmarli członkowie w 1. półroczu 1907 r.). 
Ks. J. Wadowski był przede wszystkim historykiem, a jako kaznodzieja upamiętnił się tylko jedną pozycją. Jest nią mowa pogrzebowa, wydana drukiem anonimowo, poświęcona Janowi Baranowskiemu, którego pogrzeb odbył się w Lublinie 12 listopada 1879 r. ${ }^{78}$ Jan Baranowski (ur. 1800 r.) przez całe niemal życie związany był zawodowo $\mathrm{z}$ astronomią i obserwatorium $\mathrm{w}$ Warszawie. Po przejściu na emeryturę, w 1870 r. osiadł w Lublinie, u swego młodszego brata Walentego, bpa lubelskiego, którego przeżył o 3 miesiące. Jest wysoce prawdopodobne, że ks. J. Wadowski dobrze znał J. Baranowskiego, skoro poświęcił mu piętnastostronicową mowę ${ }^{79}$.

Podsumowując należy zauważyć, że ks. Jan Ambroży Wadowski był kapłanem przez 45 lat, w tym czasie przez okres siedemnastoletni wykładał historię Kościoła. Niemal do końca życia prowadził badania naukowe nad historią Kościoła szczególnie $\mathrm{w}$ regionie lubelskim ${ }^{80}$. W rękopisie pozostawił kilkanaście tysięcy stron, w tym np. 266 opracowanych monografii kościołów diecezji lubelskiej i 186 podlaskiej. Ze względu na fakt, że w czasie I i II wojny światowej straconych zostało wiele oryginalnych dokumentów, jego spuścizna stanowi nieocenione źródło do badań nad historią Kościoła ${ }^{81}$.

W jego materiałach znajdujących się w Bibliotece PAU i PAN, historycy mogą nadal odnaleźć interesujące ich zagadnienia. Należy nadmienić, że rękopisy stanowiące jego materiały (sygn. 2335-2392 oraz 3259-3279) zostały mikrofilmowane przez Bibliotekę Narodową najprawdopodobniej pod koniec lat 70 . XX w. Mikrofilmy te znajdują się zatem w BN w Warszawie, a ich kopie także w Bibliotece Naukowej PAU i PAN w Krakowie. Niemożliwe jest jednoznaczne stwierdzenie, jaką popularnością wśród badaczy cieszy się spuścizna ks. J. Wadowskiego. Istnienie mikrofilmów powoduje, że oryginały nie są udostępniane, a do chwili ich pojawienia się, na towarzyszącej każdemu rękopisowi metryczce korzystający wpisywali swoje nazwiska i cel badań. Wpisów takich nie jest wiele. Z pozostałej części spuścizny ks. J. Wadowskiego (sygn. 12 836-12 846), których opis znajduje się w katalogu kartkowym, nikt do tej pory nie korzystał.

słowa kluczowe: ks. Jan Wadowski, historia Kościoła, spuścizna rękopiśmienna, diecezja lubelska, kościoły, Lublin

${ }^{78}$ [J.A. Wadowski], Mowa przy zwłokach ś.p. Jana Baranowskiego, b. dyrektora obserwatorium astron. warsz. $w$ katedrze lubelskiej podczas żałobnego nabożeństwa za spokój duszy jego, dnia 12 listopada 1879 r. wypowiedziana, Kraków 1880. (Estr. VII, 231).

${ }^{79}$ S. Dickstein, J. Gadomski, Baranowski Jan, PSB, t. 1, Kraków 1935, s. 280-281; Z. Olszamowska-Skowrońska, Baranowski Walenty, PSB, t. 1, Kraków 1935, s. 285-286.

${ }^{80}$ Stopniak, Z działalności naukowej, s. 57.

${ }^{81}$ Tenże, Wadowski Jan Ambroży, s. 376-377. 


\section{BIBLIOGRAFIA}

\section{Źródła rękopiśmienne}

Biblioteka im. H. Łopacińskiego w Lublinie, rkps 2253.

Biblioteka Naukowa PAU i PAN w Krakowie, rkps 2335-2381, 2383-2387 t. 1-4, 23892392, 3262-3279 t.1-6, 3288, 7935, 12 836-12 846.

\section{Źródła drukowane i opracowania}

Bender R., Łopaciński Hieronim Rafał, w: Polski Słownik Biograficzny, t. 18, Wrocław -Warszawa-Kraków-Gdańsk 1973.

Dickstein S., Gadomski J., Baranowski Jan, w: Polski Słownik Biograficzny, t. 1, Kraków 1935.

Domański M., Wadowski Jan Ambroży, w: Słownik biograficzny miasta Lublina, t. 1, red. T. Radzik, J. Skarbek, A.A. Witusik, Lublin 1992.

Grychowski A., Lublin i Lubelszczyzna w życiu i twórczości pisarzy polskich od średniowiecza do 1968 r., Lublin 1974.

Katalog rękopisów Biblioteki PAN w Krakowie. Sygnatury 2299-2630, oprac. Z. Jabloński, A. Preissner i B. Schnaydrowa, Wrocław-Warszawa-Kraków 1967.

Katalog rękopisów Biblioteki PAN w Krakowie. Sygnatury 2907-3606, oprac. J. Dużyk, B. Schnaydrowa, pod red. Z. Jabłońskiego, Wrocław-Warszawa-Kraków- Gdańsk 1973.

Kureczko J., Mowa żałobna miana na pogrzebie ś.p. prałata kapituły zamojskiej Jana Ambrożego Wadowskiego w Lublinie 27 maja 1907 [...], Lublin 1907.

Nieciowa E.H., Członkowie Polskiej Akademii Umiejętności 1872-1952, Wrocław-Warszawa-Kraków-Gdańsk 1973.

Olszamowska-Skowrońska, Baranowski Walenty, w: Polski Słownik Biograficzny, t. 1 Kraków 1935.

Starnawski J., Sylwetki lubelskich humanistów XIX i pierwszej połowy XX wieku, Lublin 2004.

Stopniak F., Wadowski Jan Ambroży, w: Słownik polskich teologów katolickich, t. 7, red. H.E. Wyczawski OFM, Warszawa 1983.

Stopniak F., Z działalności naukowej ks. Jana Ambrożego Wadowskiego kanonika zamojskiego, „Wiadomości Diecezjalne Lubelskie”, R. 34:1960.

Wadowski Jan Ambroży, w: Podręczna Encyklopedia Kościelna, t. 41-42, oprac. J. i A. Archutowscy, Warszawa-Lublin, Łódź 1915.

Wadowski J. A., Kościoły lubelskie, Lublin 2004 (reprint).

Wadowski J.A., Materiały i opracowania dotyczące historii wyższych zakładów naukowych w Polsce, t. 1, Warszawa 1899-1900.

Wadowski J.A., Mowa przy zwłokach ś.p. Jana Baranowskiego, b. dyrektora obserwatorium astronom. warsz. w katedrze lubelskiej podczas żałobnego nabożeństwa za spokój duszy jego, dnia 12 listopada 1879 r. wypowiedziana, Kraków 1880. 


\title{
REV. JAN AMBROŻY WADOWSKI'S MANUSCRIPT LEGACY IN THE SCIENTIFIC LIBRARY OF THE POLISH ACADEMY OF LEARNING AND THE POLISH ACADEMY OF SCIENCES IN CRACOW
}

\begin{abstract}
Summary
Rev. Jan Ambroży Wadowski (1839-1907) was a Dominican. In 1866 he became a secular priest working in Włocławek, and from 1877 in the Diocese of Lublin and Lublin itself. He was not only a priest but also a historian dealing mainly with the history of the Church. For decades, he made copies of archival materials of interest to him, he made excerpts and notes useful in his work. He also collected original documents of historical value. He did not publish much, but the works which were published by him were significant, among other things, Kościoły lubelskie (Churches of Lublin) and Anacephaleosis professorum Academiae Zamoscensis. His numerous manuscripts were placed at the Academy of Learning in Cracow in 1909 as Antoni Wadowski's gift. Currently, they are stored in the Scientific Library of the Polish Academy of Learning and the Polish Academy of Sciences in Cracow. His collection includes a total of 90 catalogue numbers in 100 volumes. Most of this heritage was described in catalogues printed in the 1960s and 1970s. And the remainder part, recently discovered, was catalogued in 2012. Rev. Wadowski's manuscripts include, among other things, materials for the history of various churches and monasteries in Lublin, Zamość and other places in the Diocese of Lublin and Chełm; biographical materials; various records of political and economic content. He used some information from those materials for his publications. Given the fact that during the First and the Second World War a number of documents were lost, Rev. Wadowski's legacy is an invaluable source on the history of the Church on Polish soil.
\end{abstract}

Keywords: Rev. Jan Wadowski, the history of the Church, manuscript legacy, the Diocese of Lublin, churches, Lublin 